\section{Data report: Miocene planktonic foraminifers Dentoglobigerina and Globoquadrina from IODP Sites U1489 and U1490, Expedition $363^{1}$}

\author{
Florent Fayolle ${ }^{2}$ and Bridget S. Wade ${ }^{2}$
}

Keywords: International Ocean Discovery Program, IODP, JOIDES Resolution, Expedition 363, Pacific Warm Pool, Site U1489, Site U1490, planktonic foraminifers, Miocene

\author{
1 Abstract \\ 1 Introduction \\ 1 Site location and setting \\ 2 Methods and materials \\ 2 Results \\ 2 Acknowledgments \\ 2 References \\ 4 Appendix
}

\begin{abstract}
International Ocean Discovery Program Expedition 363 Sites U1489 and U1490, located in the Western Pacific Warm Pool, contain diverse assemblages of planktonic foraminifers. We examined and imaged specimens of Miocene Dentoglobigerina and Globoquadrina to determine the presence or absence of spine holes and pustules in their wall texture. A total of 15 specimens were observed across six species, including Dentoglobigerina baroemoenensis, Dentoglobigerina binaiensis, Dentoglobigerina globosa, Dentoglobigerina globularis, Dentoglobigerina tripartita, and Globoquadrina dehiscens. Here we present scanning electron microscope and $\mathrm{z}-$ stacking light microscope images in three views, including illustrations of their wall texture.
\end{abstract}

\section{Introduction}

Dentoglobigerina is a diverse genus of planktonic foraminifers that ranges from the middle Eocene to recent. The descendant genus Globoquadrina is currently monospecific, consisting of Globoquadrina dehiscens and ranging from the early to late Miocene (Wade et al., 2018). The taxonomy and biostratigraphy of Eocene and Oligocene Dentoglobigerina were reviewed by Olsson et al. (2006) and Wade et al. (2018), respectively, as part of the Paleogene Planktonic Foraminifera Working Group. However, the wall texture of Miocene Dentoglobigerina and Globoquadrina has not yet been examined in detail.

The dentoglobigerinids are a difficult group; in addition to morphological variability is the issue that the wall texture and the presence and absence of spine holes are highly variable across the lineage. Research to date has not been able to determine whether or not spines are a conservative trait in Miocene Dentoglobigerina. Spine holes have not been observed in all species of Dentoglobigerina (Wade et al., 2018), mostly because of the difficulty in finding well-preserved specimens and the considerable time needed to lo- cate them under a scanning electron microscope (SEM). However, given that the identification of spine holes is not evident in some species, it was suggested by Pearson and Wade (2015) that there could be two clades with similar morphologies, one spinose and one nonspinose, or that spines could have been lost through evolution. Pustules are also of interest for this study because they are frequently seen in umbilical shoulders of Dentoglobigerina specimens. Here we contribute to the debate on Miocene Dentoglobigerina and Globoquadrina wall texture and taxonomy through light microscope (z-stacking) and SEM examination of specimens from Sites U1489 and U1490 in three views (umbilical, edge, and spiral). We also include wall texture images and record the presence or absence of spine holes and pustules around the umbilical area.

\section{Site location and setting}

Seven sites were cored in 2016 during International Ocean Discovery Program Expedition 363 in the Western Pacific Warm Pool (Figure F1). We examined two sites to record the presence of Dentoglobigerina and Globoquadrina: Site U1489 cored four holes at 3400 meters below sea level (mbsl), and Site U1490 cored three holes at $2300 \mathrm{mbsl}$ (Rosenthal et al., 2018a). This data report focuses on the Dentoglobigerina and Globoquadrina genera found in lower to middle Miocene sediments. The geological age of the sediment samples ranges from 22.13 to $13.27 \mathrm{Ma}$ according to the shipboard age model (Rosenthal et al., 2018a).

Site U1489 $\left(02^{\circ} 07.19 \mathrm{~N}, 141^{\circ} 01.67^{\prime} \mathrm{E}\right)$ is situated on the western slope of the southern Eauripik Rise in the Caroline basin of Papua New Guinea (Figure F1; Rosenthal et al., 2018b). Site U1490 $\left(05^{\circ} 48.95 \mathrm{~N}, 142^{\circ} 39.27^{\prime} \mathrm{E}\right)$ is located on the northern edge of the Eauripik Rise about $431 \mathrm{~km}$ north of Site U1489 (Figure F1; Rosenthal et al., 2018c). Of the seven total holes cored at Sites U1489 and U1490, Holes U1489D and U1490A are examined in the present study.

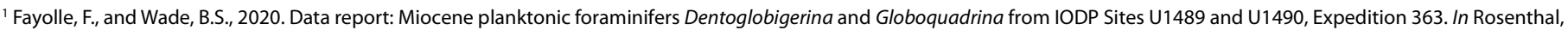
Y., Holbourn, A.E., Kulhanek, D.K., and the Expedition 363 Scientists, Western Pacific Warm Pool. Proceedings of the International Ocean Discovery Program, 363 : College Station, TX (International Ocean Discovery Program). https://doi.org/10.14379/iodp.proc.363.203.2020

2 Department of Earth Sciences, University College London, UK. Correspondence author: florent.fayolle.18@alumni.ucl.ac.uk

MS 363-203: Received 12 February 2020 . Accepted 16 July 2020 . Published 13 November 2020

This work is distributed under the Creative Commons Attribution 4.0 International (CC BY 4.0) license. (cc) BY
} 
Figure F1. Bathymetric map of the equatorial Pacific Ocean indicating locations of Site U1489 $\left(02^{\circ} 07.19^{\prime} \mathrm{N}, 141^{\circ} 01.67^{\prime} \mathrm{E} ; 3400 \mathrm{mbsl}\right)$ and Site U1490 $\left(05^{\circ} 48.95^{\prime} \mathrm{N}, 142^{\circ} 39.27^{\prime} \mathrm{E} ; 2300 \mathrm{mbsl}\right)$ on the Eauripik Rise in the Western Pacific Warm Pool. Contour interval $=500 \mathrm{~m}$. Bathymetric data from Amante and Eakins (2009); figure modified from Rosenthal et al. (2018a).

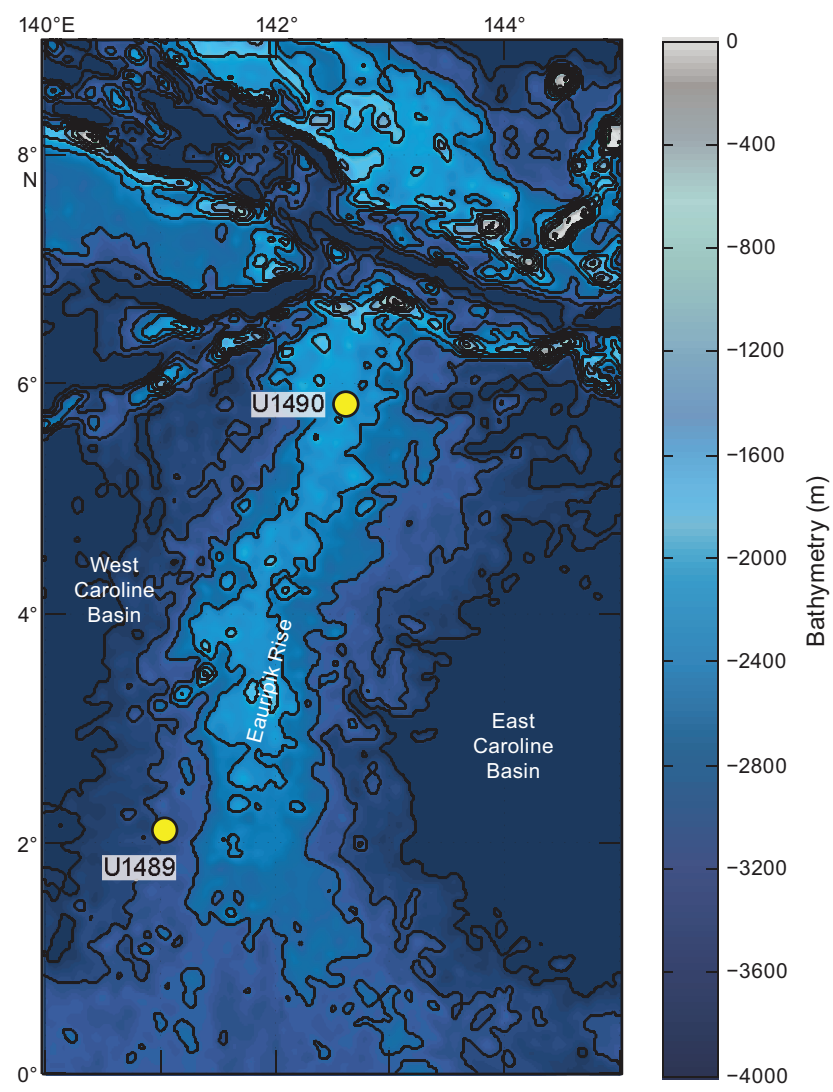

\section{Methods and materials}

Sites U1489 and U1490 both recovered the lower and middle Miocene and were chosen for the relatively good preservation of planktonic foraminifers (Rosenthal et al., 2018b; Rosenthal et al., 2018c). Table T1 lists the samples analyzed, including their depth in the section and biostratigraphic age assignment. The site ages covered in this study were calibrated with the Miocene Planktonic Foraminiferal Zonation by Wade et al. (2011).

Dentoglobigerina and Globoquadrina specimens were picked manually from the residues of the $>150 \mu \mathrm{m}$ size fraction using a light microscope. A total of 15 specimens were selected across 5 samples based on their preservation. Images in three views (umbilical, edge, and spiral view) of the selected specimens were taken using an Olympus SZX10 z-stacking light microscope. A Jeol JSM6480LV high-performance SEM from the UCL Earth Sciences laboratory was used to examine wall texture and assess the presence of morphological features, including spine holes and pustules, at higher resolution. Each stub was sputter-coated in an argon and gold atmosphere using a sputter-coater machine. Spine holes were investigated across the three views of each specimen's test, and the study focused on areas where pores were sufficiently preserved, pore ridges smooth, and not affected by diagenetic processes.
Table T1. Biostratigraphic and location details of studied samples, Sites U1489 and U1490. Download table in CSV format.

Table T2. Spinose characters and pustules of selected Dentoglobigerina and Globoquadrina specimens, Sites U1489 and U1490. Download table in CSV format.

\section{Results}

At least six species belonging to the genus Dentoglobigerina, including its descendant G. dehiscens, were identified in five samples from Holes U1489D and U1490A. Morphological features (pustules and spine holes) of the wall texture of each Miocene specimen are recorded in Table $\mathbf{T} 2$, and images of each specimen are illustrated in Plates P1-P15. Overall, the preservation of specimens from Hole U1489D is better than for Hole U1490A.

\section{Acknowledgments}

This research used samples provided by the International Ocean Discovery Program (IODP). Funding for this research was provided by Natural Environment Research Council grant number NE/P016642. We thank Jim Davy for assistance with SEM preparation and Marcin Latas for help with the $\mathrm{z}$-stacking light microscope. The manuscript was improved by a review from Kirsty Edgar and comments from Denise Kulhanek. Florent Fayolle acknowledges funding from the Geologists' Association Curry Award.

\section{References}

Amante, C., and Eakins, B.W., 2009. ETOPO1 1 Arc-Minute Global Relief Model: Procedures, Data Sources and Analysis. NOAA Technical Memorandum NESDIS NGDC-24. National Geophysical Data Center, NOAA. https://doi.org/10.7289/V5C8276M

Bermúdez, P.J., 1961. Contribucion al estudio de las Globigerindea de la region Caribe-Antillana (Paleocene-Reciente): Boletino Geologia (Venezuela). Memoria Congres de Geologia Venezolano, 3:1119-1393.

Blow, W.H., 1979. The Cainozoic Globigerinida: A Study of the Morphology, Taxonomy, Evolutionary Relationships and the Stratigraphical Distribution of Some Globigerinida (mainly Globigerinacea): Leiden, The Netherlands (E.J. Brill).

Bolli, H.M., 1957. The genera Globigerina and Globorotaria in Paleocenelower Eocene Lizard Springs Formation of Trinidad, BWI. Bulletin of the United States National Museum, 215:61-81.

Carpenter, W.B., Parker, W.K., and Jones, T.R., 1862. Introduction to the Study of the Foraminifera: London (R. Hardwicke). https://doi.org/10.5962/bhl.title.9133

Chapman, F., Parr, W.J., and Collins, A.C., 1934. Tertiary foraminifers of Victoria, Australia: the Balcombian deposits of Port Philip (Pt. III). Journal of the Linnean Society of London, Zoology, 38(262):553-577. https://doi.org/10.1111/j.1096-3642.1934.tb00996.x

d'Orbigny, A.D., 1826. Tableau methodique de la classe des Foraminiféres. Annales des Sciences Naturrelles, 7:245-314.

Finlay, H.J., 1947. New Zealand Foraminifera: key species in stratigraphy No. 5. New Zealand Journal of Science and Technology, 28:259-292.

Fox, L.R., and Wade, B.S., 2013. Systematic taxonomy of early-middle Miocene planktonic foraminifera from the equatorial Pacific Ocean: Integrated Ocean Drilling Program, Site U1338. Journal of Foraminiferal Research, 43(4):374-405. https://doi.org/10.2113/gsjfr.43.4.374

Koch, R., 1935. Namensänderung einiger Tertiär-Foraminiferen aus Neiderländisch Ost-Indien. Eclogae Geologicae Helvetiae, 28:557-558. 
Koch, R.E. 1926. Mitteltertiäre Foraminiferen aus Bulongan, Ost-Borneo. Eclogae Geologicae Helvetiae, 19(3):722-759.

Leckie, R.M., Farnham, C., and Schmidt, M.G., 1993. Oligocene planktonic foraminifer biostratigraphy of Hole 803D (Ontong Java Plateau) and Hole 628A (Little Bahama Bank), and comparison with the southern high latitudes. In Berger, W.H., Kroenke, L.W., Mayer, L.A., et al. (Eds.), Proceedings of the Ocean Drilling Program, Scientific Results: College Station, TX (Ocean Drilling Program), 130:113-136. https://doi.org/10.2973/odp.proc.sr.130.012.1993

LeRoy, L.W., 1939. Some small foraminifera, Ostracoda and otoliths from the Neogene (Miocene) of the Rokan-Tapanoeli area, central Sumatra. Natuurkundig Tijdschrift voor Nederlandsch Indie, 99(6):215-296.

Olsson, R.K., Hemleben, C., and Pearson, P.N., 2006. Taxonomy, biostratigraphy, and phylogeny of Eocene Dentoglobigerina. In Pearson, P.N., Olsson, R.K., Huber, B.T., Hemleben, C., and Berggren, W.A. (Eds.), Atlas of Eocene Planktonic Foraminifera. Special Publication - Cushman Foundation for Foraminiferal Research, 41:401-412.

Pearson, P.N., and Wade, B.S., 2009. Taxonomy and stable isotope paleoecology of well-preserved planktonic foraminifera from the uppermost Oligocene of Trinidad. Journal of Foraminiferal Research, 39(3):191-217. https://doi.org/10.2113/gsjfr.39.3.191

Pearson, P.N., and Wade, B.S., 2015. Systematic taxonomy of exceptionally well-preserved planktonic foraminifera from the Eocene/Oligocene boundary of Tanzania. Special Publication - Cushman Foundation for Foraminiferal Research, 45:1-85. https://discovery.ucl.ac.uk/id/eprint/1475039

Rosenthal, Y., Holbourn, A.E., Kulhanek, D.K., Aiello, I.W., Babila, T.L., Bayon, G., Beaufort, L., Bova, S.C., Chun, J.-H., Dang, H., Drury, A.J., Dunkley Jones, T., Eichler, P.P.B., Fernando, A.G.S., Gibson, K.A., Hatfield, R.G., Johnson, D.L., Kumagai, Y., Li, T., Linsley, B.K., Meinicke, N., Mountain, G.S., Opdyke, B.N., Pearson, P.N., Poole, C.R., Ravelo, A.C., Sagawa, T., Schmitt, A., Wurtzel, J.B., Xu, J., Yamamoto, M., and Zhang, Y.G., 2018 a. Expedition 363 summary. In Rosenthal, Y., Holbourn, A.E., Kulhanek, D.K., and the Expedition 363 Scientists, Western Pacific Warm Pool. Proceedings of the International Ocean Discovery Program, 363: College Station, TX (International Ocean Discovery Program).

https://doi.org/10.14379/iodp.proc.363.101.2018
Rosenthal, Y., Holbourn, A.E., Kulhanek, D.K., Aiello, I.W., Babila, T.L., Bayon, G., Beaufort, L., Bova, S.C., Chun, J.-H., Dang, H., Drury, A.J., Dunkley Jones, T., Eichler, P.P.B., Fernando, A.G.S., Gibson, K.A., Hatfield, R.G., Johnson, D.L., Kumagai, Y., Li, T., Linsley, B.K., Meinicke, N., Mountain, G.S., Opdyke, B.N., Pearson, P.N., Poole, C.R., Ravelo, A.C., Sagawa, T., Schmitt, A., Wurtzel, J.B., Xu, J., Yamamoto, M., and Zhang, Y.G., 2018 b. Site U1489. In Rosenthal, Y., Holbourn, A.E., Kulhanek, D.K., and the Expedition 363 Scientists, Western Pacific Warm Pool. Proceedings of the International Ocean Discovery Program, 363: College Station, TX (International Ocean Discovery Program). https://doi.org/10.14379/iodp.proc.363.110.2018

Rosenthal, Y., Holbourn, A.E., Kulhanek, D.K., Aiello, I.W., Babila, T.L., Bayon, G., Beaufort, L., Bova, S.C., Chun, J.-H., Dang, H., Drury, A.J., Dunkley Jones, T., Eichler, P.P.B., Fernando, A.G.S., Gibson, K.A., Hatfield, R.G., Johnson, D.L., Kumagai, Y., Li, T., Linsley, B.K., Meinicke, N., Mountain, G.S., Opdyke, B.N., Pearson, P.N., Poole, C.R., Ravelo, A.C., Sagawa, T., Schmitt, A., Wurtzel, J.B., Xu, J., Yamamoto, M., and Zhang, Y.G., 2018c. Site U1490. In Rosenthal, Y., Holbourn, A.E., Kulhanek, D.K., and the Expedition 363 Scientists, Western Pacific Warm Pool. Proceedings of the International Ocean Discovery Program, 363: College Station, TX (International Ocean Discovery Program).

https://doi.org/10.14379/iodp.proc.363.111.2018

Wade, B.S., Berggren, W.A., and Olsson, R.K., 2007. The biostratigraphy and paleobiology of Oligocene planktonic foraminifera from the equatorial Pacific Ocean (ODP Site 1218). Marine Micropaleontology, 62(3):167179. https://doi.org/10.1016/j.marmicro.2006.08.005

Wade, B.S., Pearson, P.N., Berggren, W.A., and Pälike, H., 2011. Review and revision of Cenozoic tropical planktonic foraminiferal biostratigraphy and calibration to the geomagnetic polarity and astronomical time scale. Earth-Science Reviews, 104(1-3):111-142. https://doi.org/10.1016/j.earscirev.2010.09.003

Wade, B.S., Pearson, P.N., Olsson, R.K., Fraass, A.J., Leckie, R.M., and Hemleben, C., 2018. Taxonomy, biostratigraphy, and phylogeny of Oligocene and lower Miocene Dentoglobigerina and Globoquadrina. In Wade, B.S., Olsson, R.K., Pearson, P.N., Huber, B.T., and Berggren, W.A. (Eds.), Atlas of Oligocene Planktonic Foraminifera. Special Publication - Cushman Foundation for Foraminiferal Research, 46:331-384. https://discovery.ucl.ac.uk/id/eprint/10049514 


\section{Appendix}

\section{Systematic paleontology of selected taxa}

Order Foraminiferida d'Orbigny, 1826

Superfamily Globigerinoidea Carpenter, Parker and Jones, 1862

Family Globigerinidae Carpenter, Parker \& Jones, 1862

Genus Dentoglobigerina Blow, 1979

Dentoglobigerina baroemoenensis (LeRoy, 1939)

(Plate P1, P2, P3, P4)

Globigerina baroemoenensis, LeRoy (1939), p. 263, pl. 6, figs. 1-2

Dentoglobigerina baroemoenensis, Wade et al. (2018), p. 335-338, pl. 11.1

Remarks: Wade et al. (2018) showed evidence for spine holes in D. baroemoenensis (pl. 11.1, fig. 12), but these were not observed by Fox and Wade (2013) (fig. 5.1c). In this report, we present additional evidence in Plate P1G-P1J with specimen S1 showing several spine holes at pore intersections in the umbilical, edge, and spiral views. One spine hole is also observed in the edge view of specimen S2 in Plate P2H. These features were found in isolated areas, mostly over the last chamber near (1) the apertural shoulders and (2) at the intersection of chambers in the spiral view. In contrast, specimens from Plates P3 and P4 did not reveal any spine holes because recrystallization and calcite overgrowth heavily obscure pore intersections. All the specimens lack pustules in the umbilical region. D. baroemoenensis was recorded in Subzone M1b and Zones M8 and M9.

\section{Dentoglobigerina binaiensis (Koch, 1935)} (Plates P5, P6)

Globigerina binaiensis, Koch (1935), p. 558, nomen novum for G. aspera Koch (1926)

Dentoglobigerina binaiensis, Wade et al. (2018), p. 338-342, pl. 11.3

Remarks: Wade et al. (2018) reported evidence for spine holes in D. binaiensis (pl. 11.3, figs. 4, 8, 12), but these were not observed by Fox and Wade (2013) (fig. 5.3b). In this report, specimens illustrated in Plates P5 and P6 did not reveal any spine holes, even though they are well preserved as illustrated by the smooth and well-defined pores and pore ridges. Specimen 55 is highly pustulose in the apertural region (Plate P5A, P5D) and to a lesser extent in the edge view (Plate P5B, P5E). Specimen S6 shows aligned pustules (Plate P6A) on the final chamber, which are particularly apparent in edge view (Plate P6E). D. binaiensis was recorded in Zone M3.

\section{Dentoglobigerina globosa (Bolli, 1957)}

(Plates P7, P8, P9)

Globoquadrina altispira globosa, Bolli (1957), p. 111, pl. 24, figs. 9a-10c Dentoglobigerina globosa, Wade et al. (2018), p. 348-350, pl. 11.6

Remarks: Fox and Wade (2013) did not record spine holes in the wall texture of D. globosa (fig. 5.6c), whereas Wade et al. (2018) did not illustrate SEM wall texture images for this species (pl. 11.6). In this report, we document the first evidence of spine holes in specimen S7 (Plate P7H). Two spine holes are found in its edge view, isolated in the last chamber and close to an intersection with two other chambers. However, no spine holes are observed in specimen S8 in Plate P8, despite the good preservation. Recrystallization (Plate
P9G, P9H) and dissolution (Plate P9I) obscure the identification of spine holes in specimen S9, illustrated in Plate P9. Pustules are observed in the apertural area of specimen S8 from Hole U1489D (Plate P8G), although they are not visible in specimens from Hole U1490A (Plates P7, P9). D. globosa was recorded in Zones M3 and M8 and Subzone M9a.

\section{Dentoglobigerina globularis (Bermúdez, 1961)}

(Plate P10)

Globoquadrina globularis, Bermúdez (1961), p. 1311, pl. 13, figs. 4-6

Dentoglobigerina globularis, Wade et al. (2018), p. 350-352, pl. 11.7

Remarks: Pearson and Wade (2009) did not record any spine hole in the wall texture of $D$. globularis (pl. 3, fig. 2d), whereas Leckie et al. (1993; pl. 3, fig. 4; pl. 2, fig. 8), Wade et al. (2007; pl. 2g, h), and Wade et al. (2018; pl. 11.7) did not illustrate SEM wall texture images for this species. Our study does not show spine holes or pustules in D. globularis, though the preservation state of the test is fairly poor because of recrystallization and infilled pores (Plates P10G-P10I). D. globularis was recorded in Subzone M1b.

Dentoglobigerina tripartita (Koch, 1926)

(Plates P11, P12, P13, P14)

Globigerina bulloides var. tripartita, Koch (1926), p. 742, fig. 21a-21b

Dentoglobigerina tripartita, Wade et al. (2018), p. 368-371, pl. 11.15

Remarks: Although the preservation of specimen S11 is good, as shown in Plate P11, we did not find direct evidence for spine holes in Miocene $D$. tripartita, nor did previous studies (Wade et al., 2018, pl. 11.15; Fox and Wade, 2013, fig. 8-3c). The rather poor preservation of other specimens (Plates P12, P13, P14), as shown by the presence of recrystallization (Plate P14I, P14J), overgrowth (Plate P12G, P12H), and dissolution in some parts of the tests (Plate $\mathbf{P 1 3 H}$ ), did not allow for the identification of spine holes. Pustules are observed in specimens illustrated in Plates P11 and P13. Specimen 11 displays numerous pustules in its apertural area (Plate P11A, P11D, P11G), and these are aligned down the umbilical suture from the edge view perspective (Plate P11B). Specimen 13 shows fewer pustules in the apertural area both from the umbilical and edge view perspectives. Also, specimen S13 in Plate P13 has a higher spire than typical specimens (Plates P11, P12, P14), and we refer to this specimen as $D$. cf. $D$. tripartita. D. tripartita was found in Subzone M1b and Zones M3, M6, and M8.

Genus Globoquadrina (Finlay, 1947)

Globoquadrina dehiscens (Chapman, Parr, and Collins, 1934) (Plate P15)

Globoquadrina dehiscens, Chapman, Parr, and Collins (1934), p. 569, pl. 11, figs. 36a-36c

Globoquadrina dehiscens, Wade et al. (2018), p. 377-380, pl. 11.17

Remarks: No spine holes were observed in G. dehiscens by Wade et al. (2018; pl. 11.17) or by Fox and Wade (2013; fig. 9-1c). Our study did not reveal any spine holes in G. dehiscens even though the preservation of specimen S15 in Plate P15 is good as shown by the smooth edges of pores (Plate P15G-P15J). Pustules are observed in the apertural area of specimen S15 both from the umbilical and edge view perspectives (Plate P15D, P15E), similar to its ancestor Dentoglobigerina. G. dehiscens is recorded in Zone M3. 
Plate P1. Dentoglobigerina baroemoenensis (S1); Sample 363-U1490A-23H-CC, 18-23 cm; middle Miocene Subzone M9a. Z-stacker images of (A) umbilical view, (B) edge view, and (C) spiral view. Scanning electron microscope (SEM) images of (D) umbilical view, (E) edge view, and (F) spiral view. Wall texture SEM images of (G) umbilical view, (H) edge view, (I) spiral view, and (J) spiral view. Evidence of spine holes. Scale bars $=100 \mu \mathrm{m}$ (whole specimens) and $10 \mu \mathrm{m}$ (close-up images).

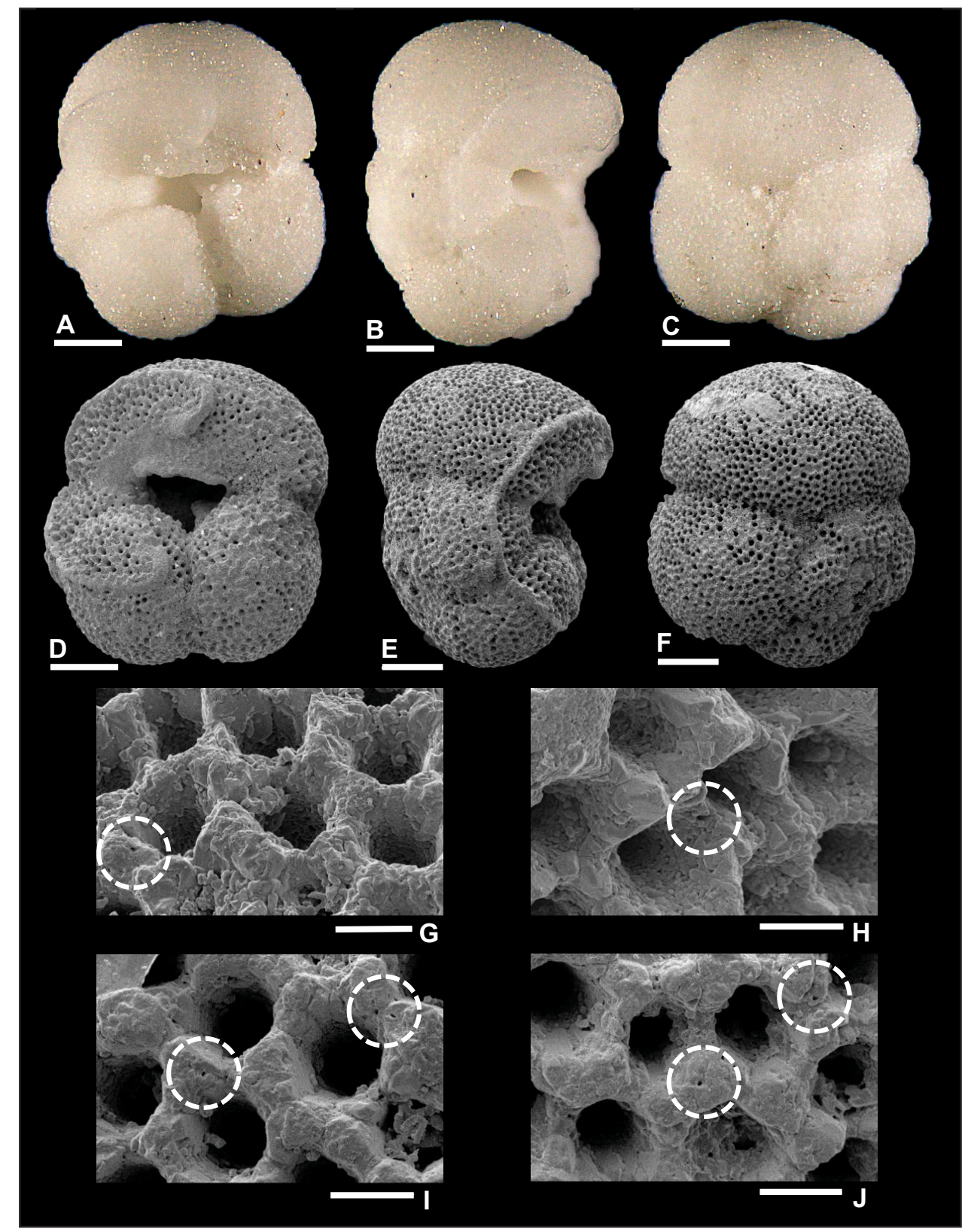


Plate P2. Dentoglobigerina baroemoenensis (S2); Sample 363-U1490A-24H-CC, 11-16 cm; middle Miocene Zone M8. Z-stacker images of (A) umbilical view, (B) edge view, and (C) spiral view. Scanning electron microscope (SEM) images of (D) umbilical view, (E) edge view, and (F) spiral view. Wall texture SEM images of (G) umbilical view, (H) edge view, and (I) spiral view. Evidence of spine holes. Scale bars $=100 \mu \mathrm{m}$ (whole specimens) and $10 \mu \mathrm{m}$ (close-up images).

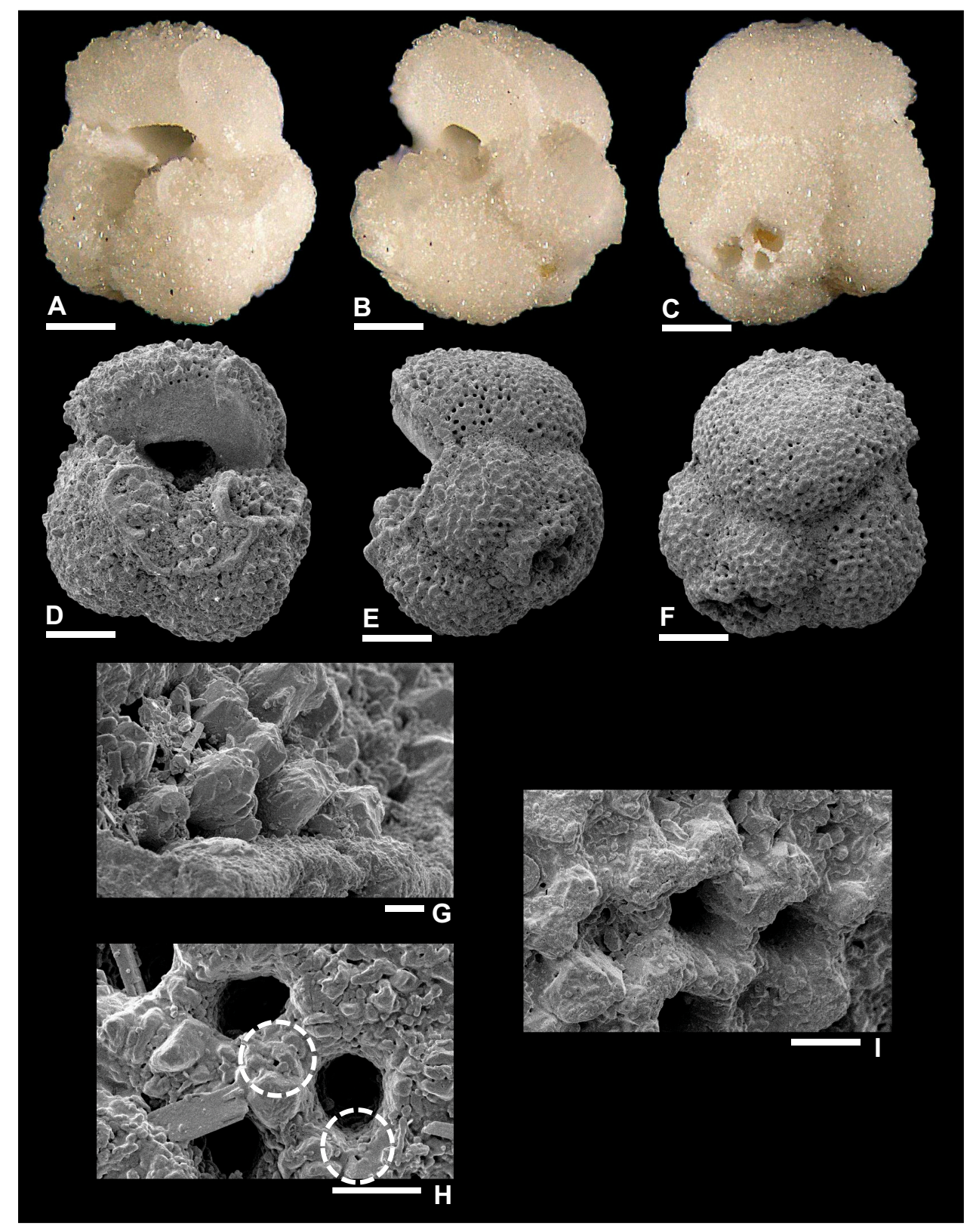


Plate P3. Dentoglobigerina baroemoenensis (S3); Sample 363-U1490A-23H-CC, 18-23 cm; middle Miocene Subzone M9a. Z-stacker images of (A) umbilical view, (B) edge view, and (C) spiral view. Scanning electron microscope (SEM) images of (D) umbilical view, (E) edge view, (F) spiral view. Wall texture SEM images of (G) umbilical view and (H) edge view. No evidence of spine holes. Scale bars $=100 \mu \mathrm{m}$ (whole specimens) and $10 \mu \mathrm{m}$ (close-up images).

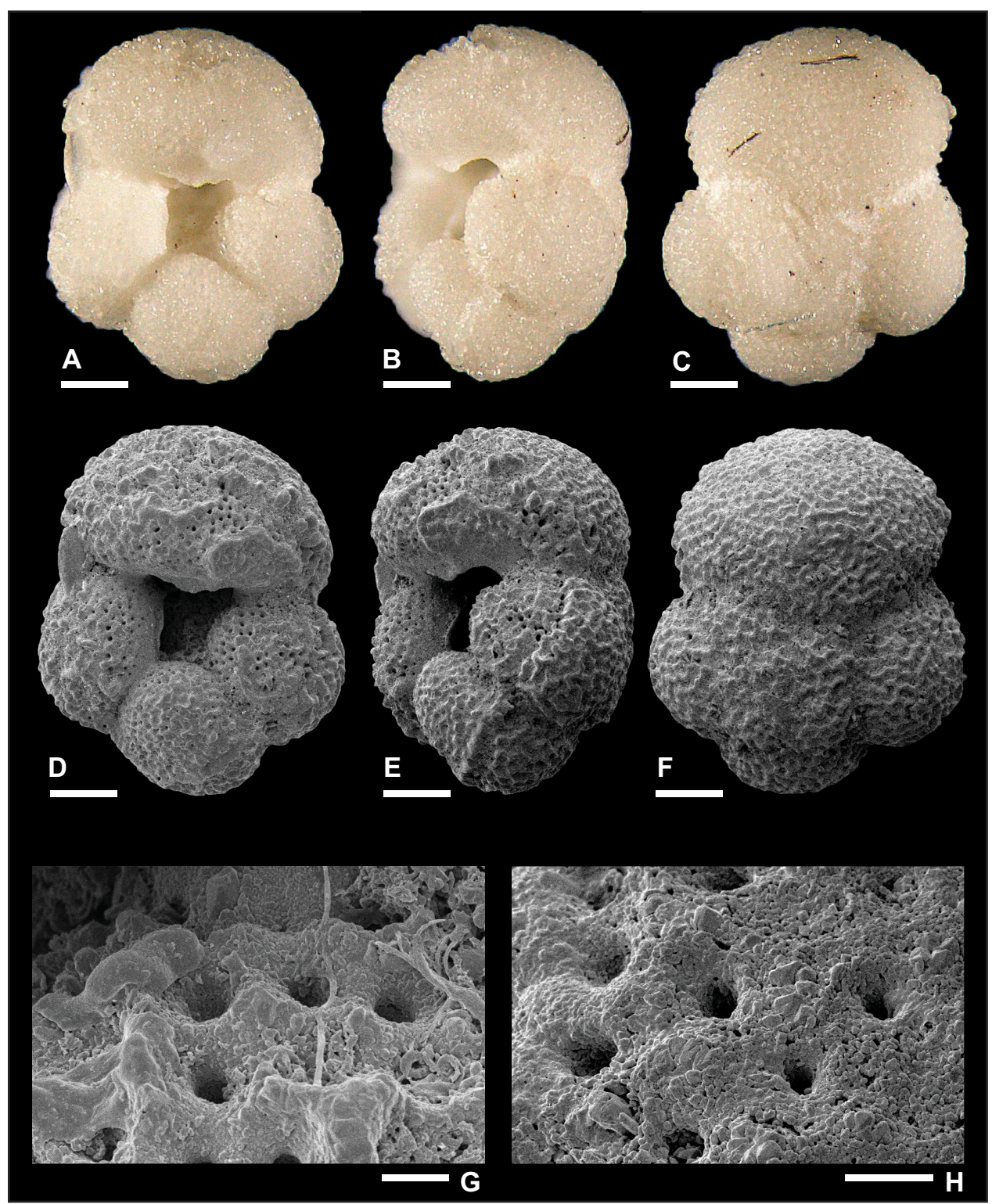


Plate P4. Dentoglobigerina baroemoenensis (S4); Sample 363-U1490A-34X-CC, 32-37 cm; lower Miocene Subzone M1b. Z-stacker images of (A) umbilical view, (B) edge view, and (C) spiral view. Scanning electron microscope (SEM) images of (D) umbilical view, (E) edge view, (F) spiral view. Wall texture SEM images of (G) umbilical view and (H) spiral view. No evidence of spine holes. Scale bars: $100=\mu \mathrm{m}$ (whole specimens) and $10 \mu \mathrm{m}$ (close-up images).

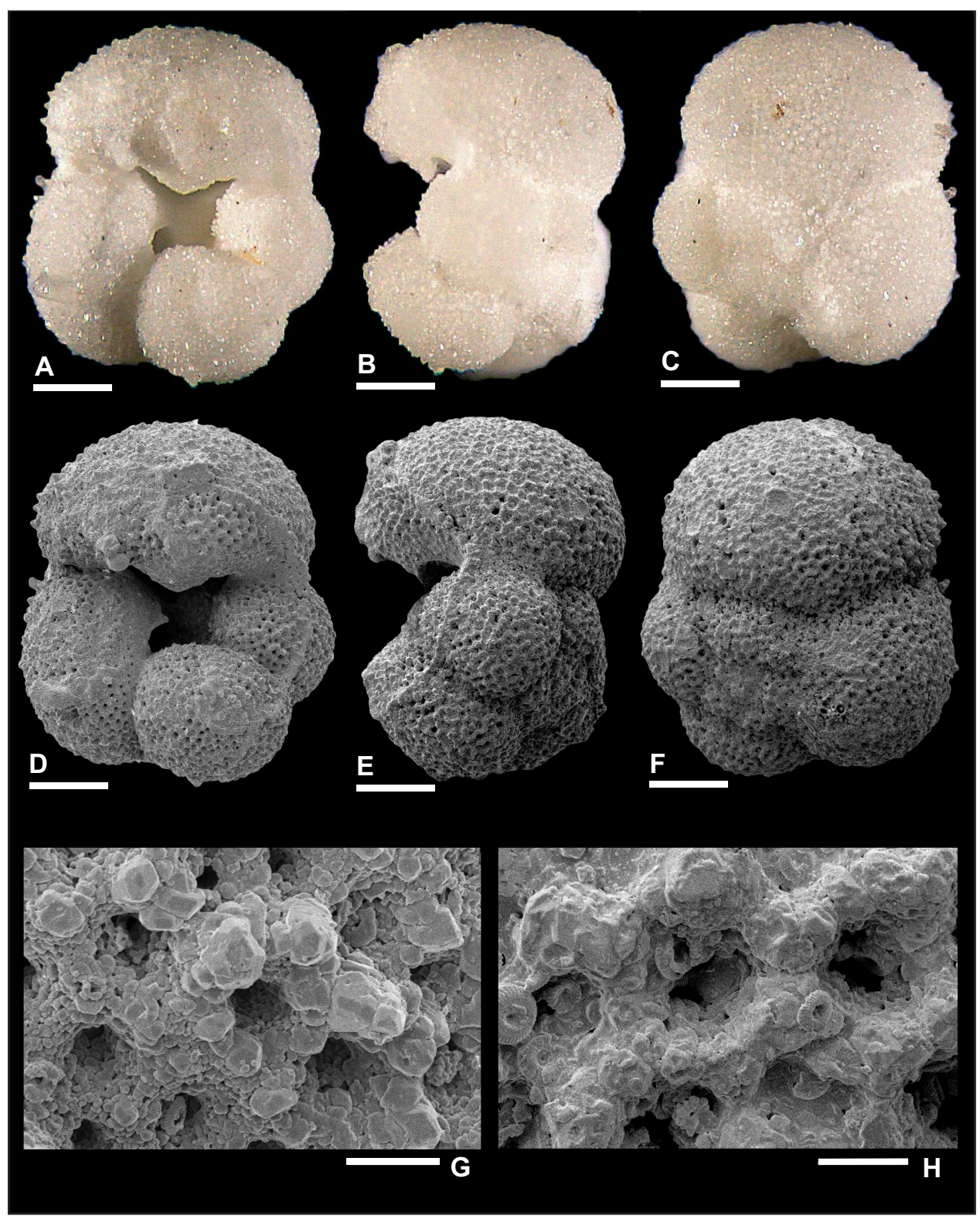


Plate P5. Dentoglobigerina binaiensis (S5); Sample 363-U1489D-27X-CC, 18-23 cm; lower Miocene Zone M3. Z-stacker images of (A) umbilical view, (B) edge view, (C) and spiral view. Scanning electron microscope (SEM) images of (D) umbilical view and (E) edge view. Spiral view not obtained. Wall texture SEM images of (F) umbilical view and (G) edge view. No evidence of spine holes. Scale bars $=100 \mu \mathrm{m}$ (whole specimens) and $10 \mu \mathrm{m}$ (close-up images).
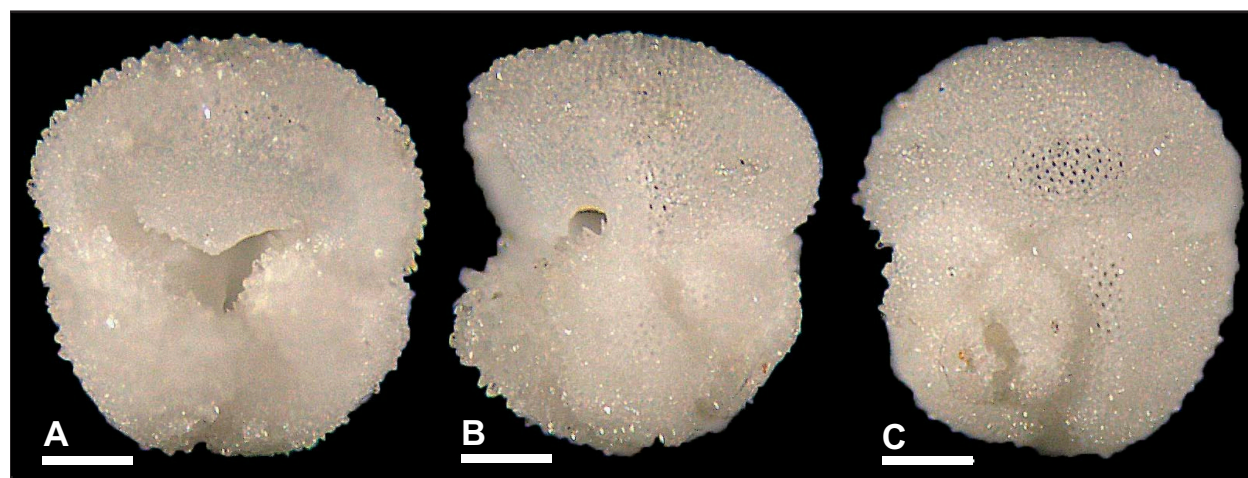

D
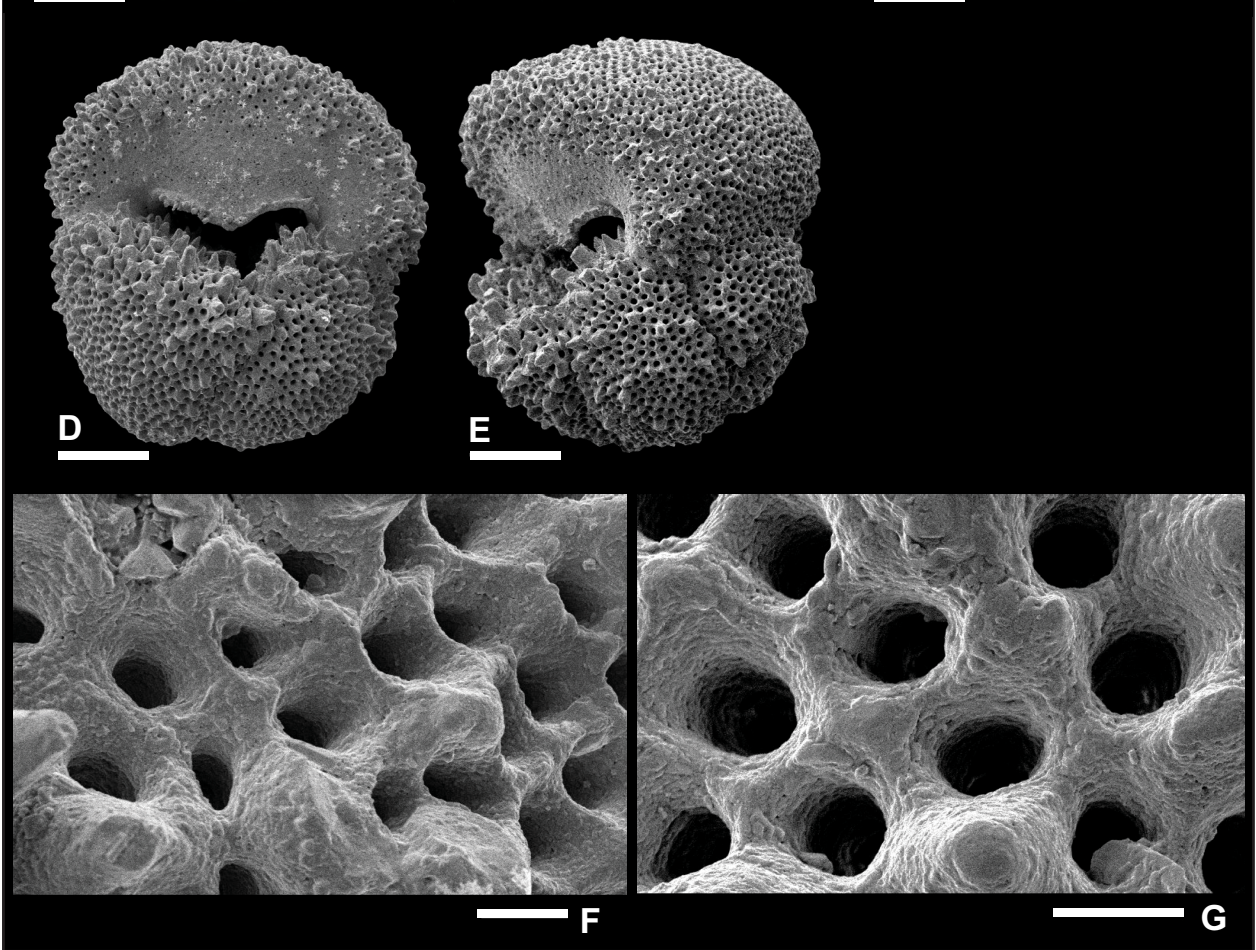
Plate P6. Dentoglobigerina binaiensis (S6); Sample 363-U1489D-27X-CC, 18-23 cm; lower Miocene Zone M3. Z-stacker images of (A) umbilical view, (B) edge view, and (C) spiral view. Scanning electron microscope (SEM) images of (D) umbilical view, (E) edge view, and (F) spiral view. Wall texture SEM images of (G) umbilical view, (H) edge view, (I) spiral view, and (J) spiral view. No evidence of spine holes. Scale bars $=100 \mu \mathrm{m}$ (whole specimens) and $10 \mu \mathrm{m}$ (close-up images).

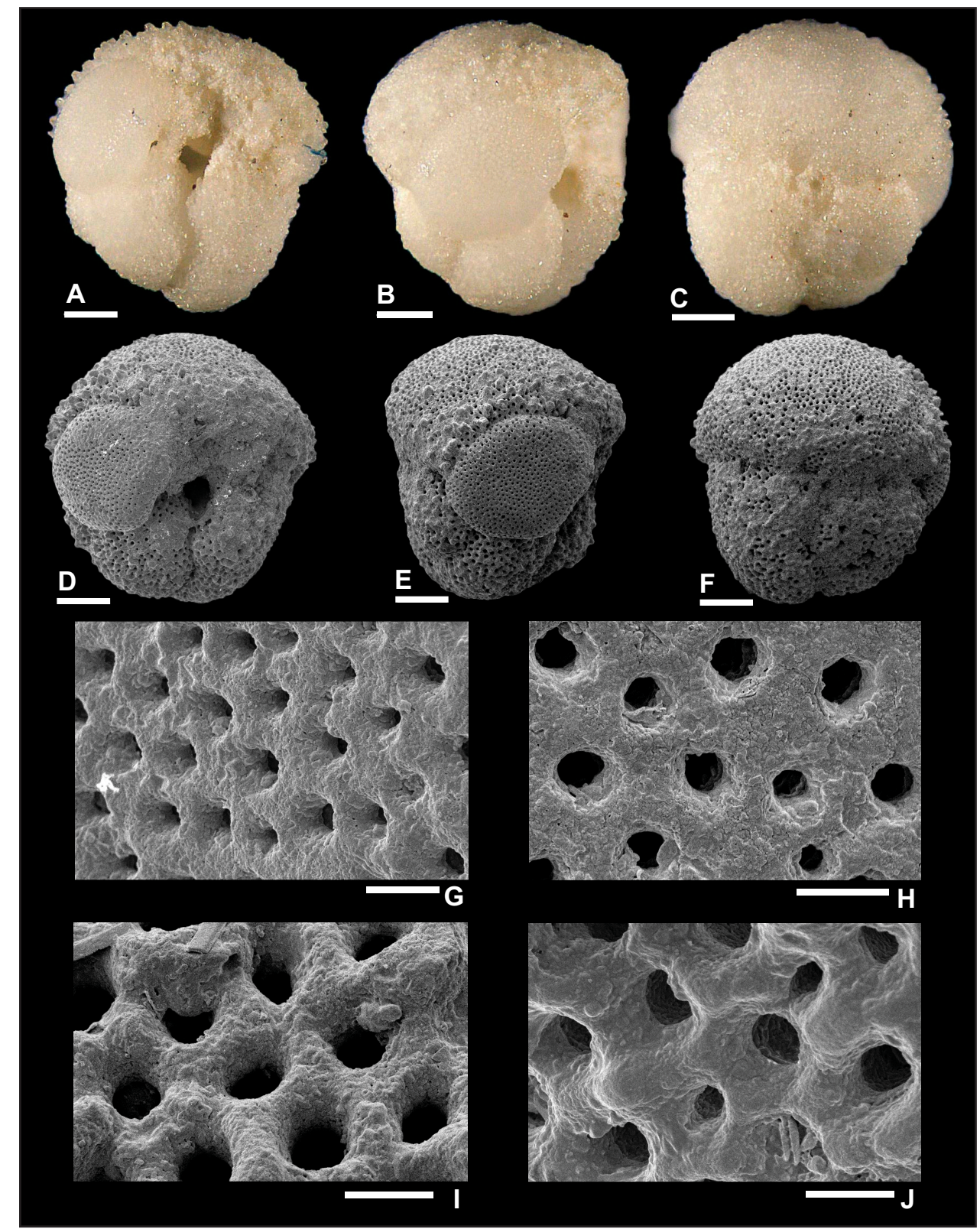


Plate P7. Dentoglobigerina globosa (S7); Sample 363-U1490A-23H-CC, 18-23 cm; middle Miocene Subzone M9a. Z-stacker images of (A) umbilical view, (B) edge view, and (C) spiral view. Scanning electron microscope (SEM) images of (D) umbilical view, (E) edge view, and (F) spiral view. Wall texture SEM images of $(G)$ umbilical view, $(H)$ edge view, (I) spiral view, and $(J)$ spiral view. Evidence of possible spine holes. Scale bars $=100 \mu \mathrm{m}($ whole specimens) and $10 \mu \mathrm{m}$ (close-up images).

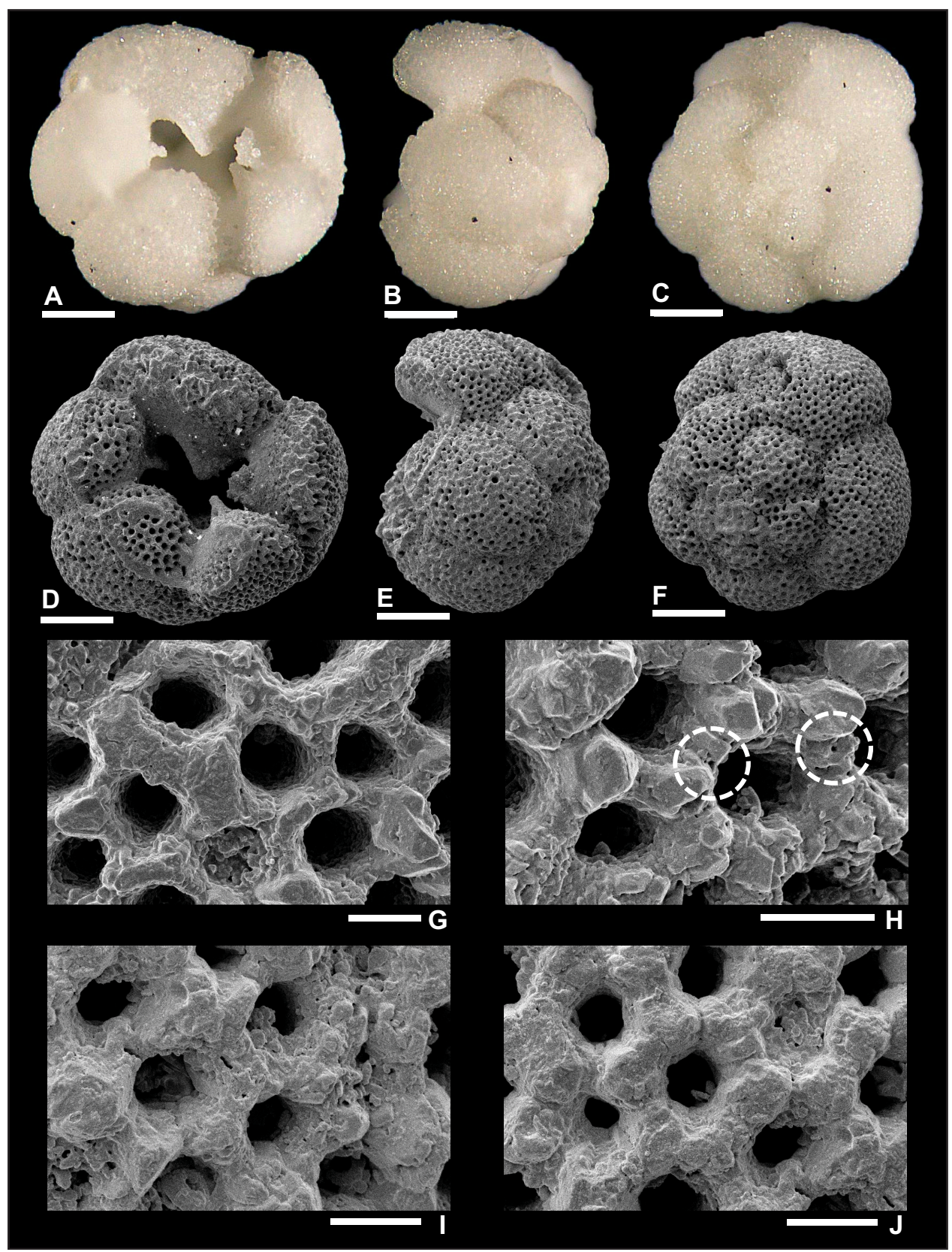


Plate P8. Dentoglobigerina globosa (S8); Sample 363-U1489D-27X-CC, 18-23 cm; lower Miocene Zone M3. Z-stacker images of (A) umbilical view, (B) edge view, and (C) spiral view. Scanning electron microscope (SEM) images of (D) umbilical view, (E) edge view, and (F) spiral view. Wall texture SEM images of (G) umbilical view, (H) edge view, (I) spiral view, and (J) spiral view. No evidence of spine holes. Scale bars $=100 \mu \mathrm{m}$ (whole specimens) and $10 \mu \mathrm{m}$ (close-up images).

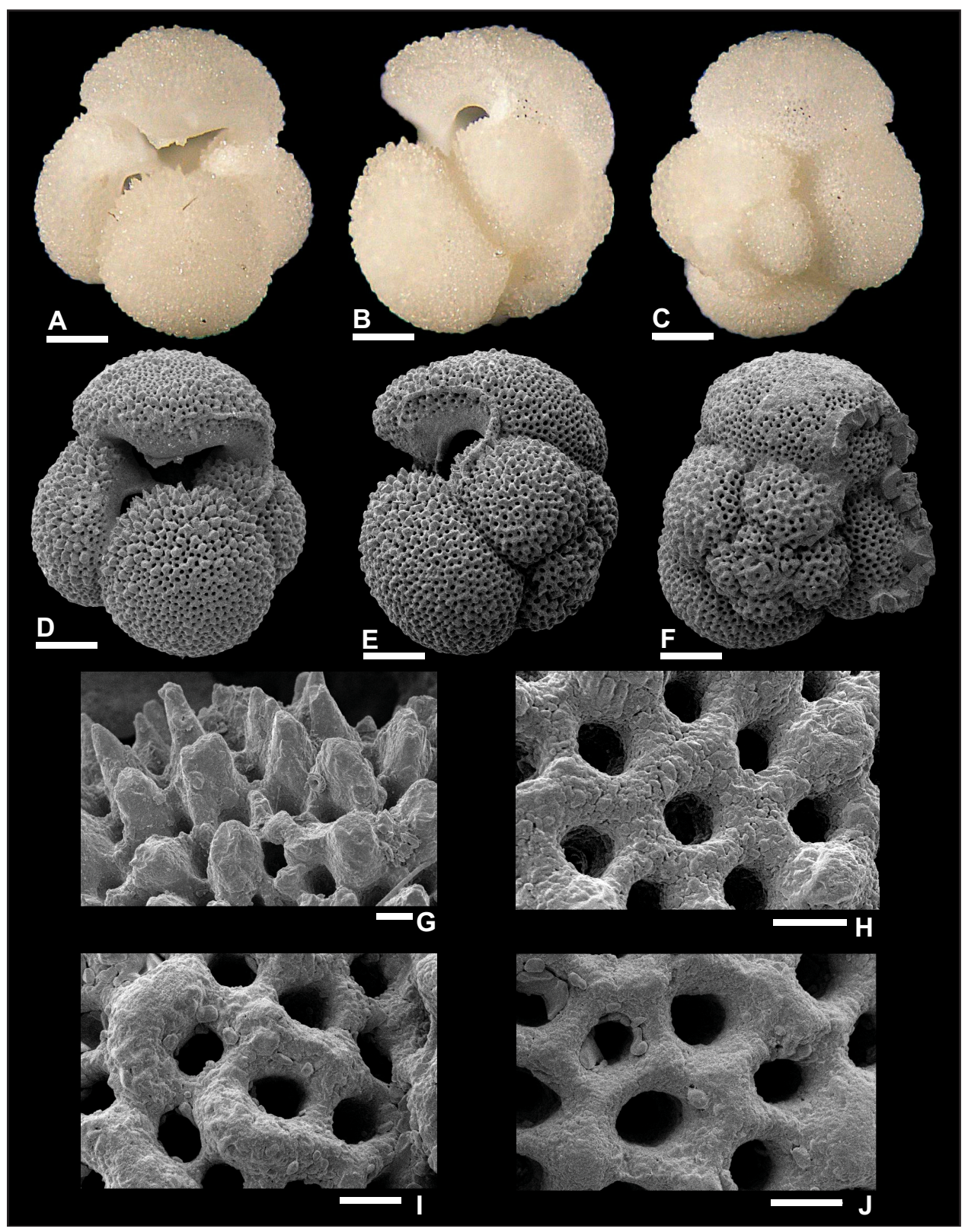


Plate P9. Dentoglobigerina globosa (S9); Sample 363-U1490A-24H-CC, 11-16 cm; middle Miocene Zone M8. Z-stacker images of (A) umbilical view, (B) edge view, and (C) spiral view. Scanning electron microscope (SEM) images of (D) umbilical view, (E) edge view, and (F) spiral view. Wall texture SEM images of (G) umbilical view, (H) edge view, and (I) spiral view. No evidence of spine holes. Scale bars $=100 \mu \mathrm{m}$ (whole specimens) and $10 \mu \mathrm{m}$ (close-up images).

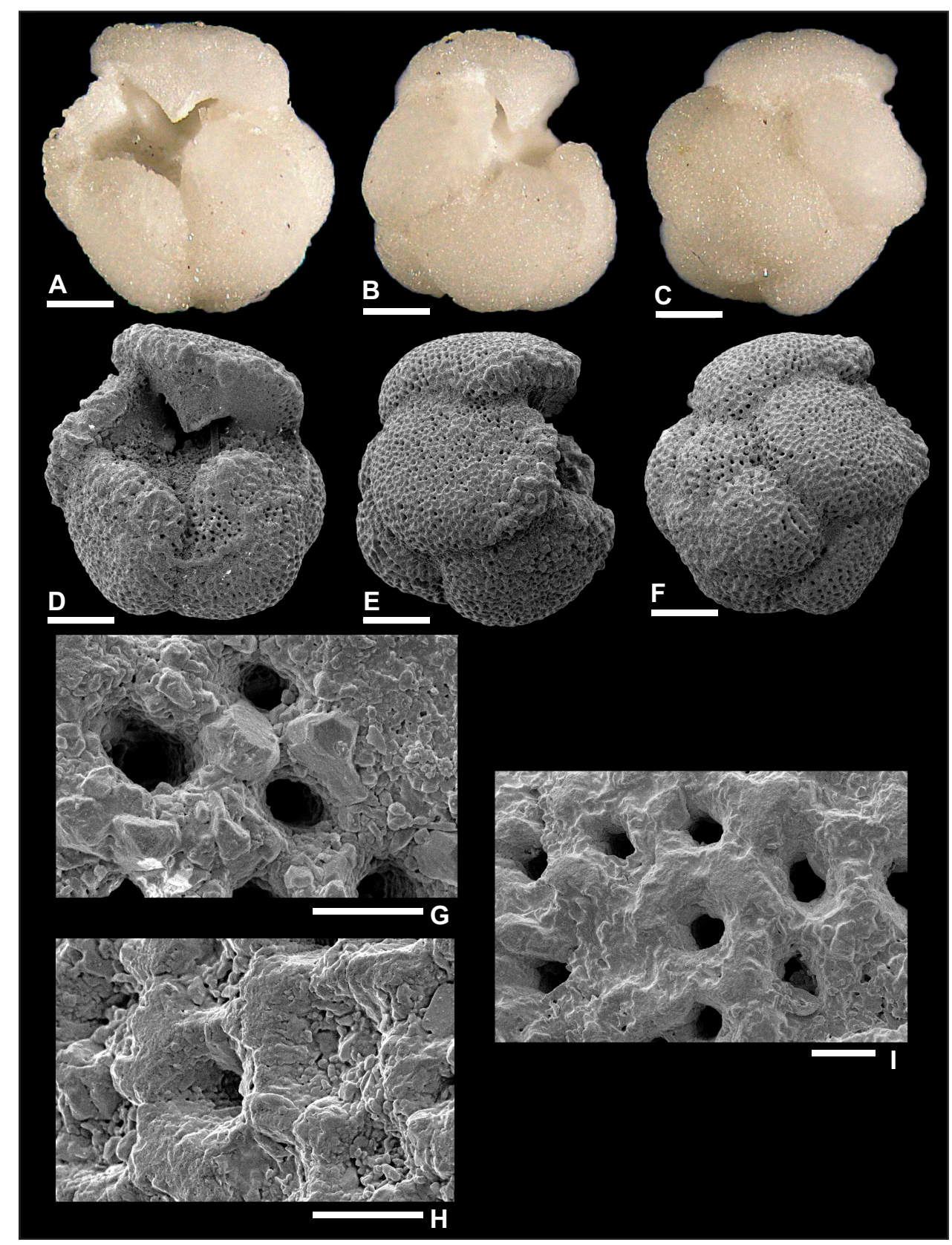


Plate P10. Dentoglobigerina globularis (S10); Sample 363-U1490A-34X-CC, 32-37 cm; lower Miocene Subzone M1b. Z-stacker images of (A) umbilical view, (B) edge view, and (C) spiral view. Scanning electron microscope (SEM) images of (D) umbilical view, (E) edge view, and (F) spiral view. Wall texture SEM images of (G) umbilical view, (H) edge view, and (I) spiral view. No evidence of spine holes. Scale bars $=100 \mu \mathrm{m}$ (whole specimens) and $10 \mu \mathrm{m}$ (close-up images).

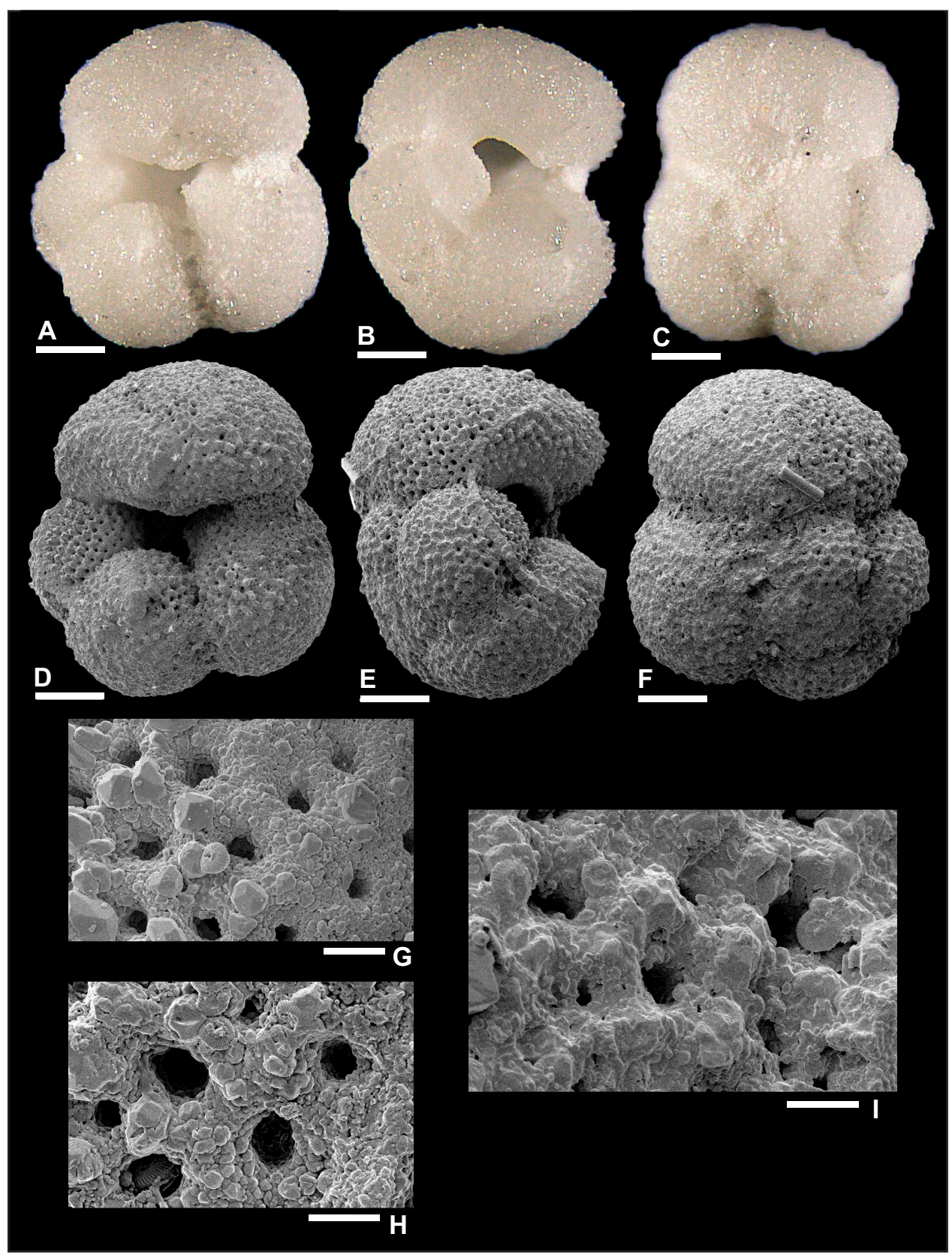


Plate P11. Dentoglobigerina tripartita (S11); Sample 363-U1489D-27X-CC, 18-23 cm; lower Miocene Zone M3. Z-stacker images of (A) umbilical view, (B) edge view, and (C) spiral view. Scanning electron microscope (SEM) images of (D) umbilical view, (E) edge view, and (F) spiral view. Wall texture SEM images of (G) umbilical view, (H) edge view, (I) spiral view, and (J) spiral view. No evidence of spine holes. Scale bars $=100 \mu \mathrm{m}$ (whole specimens) and $10 \mu \mathrm{m}(\mathrm{close}-\mathrm{up}$ images).

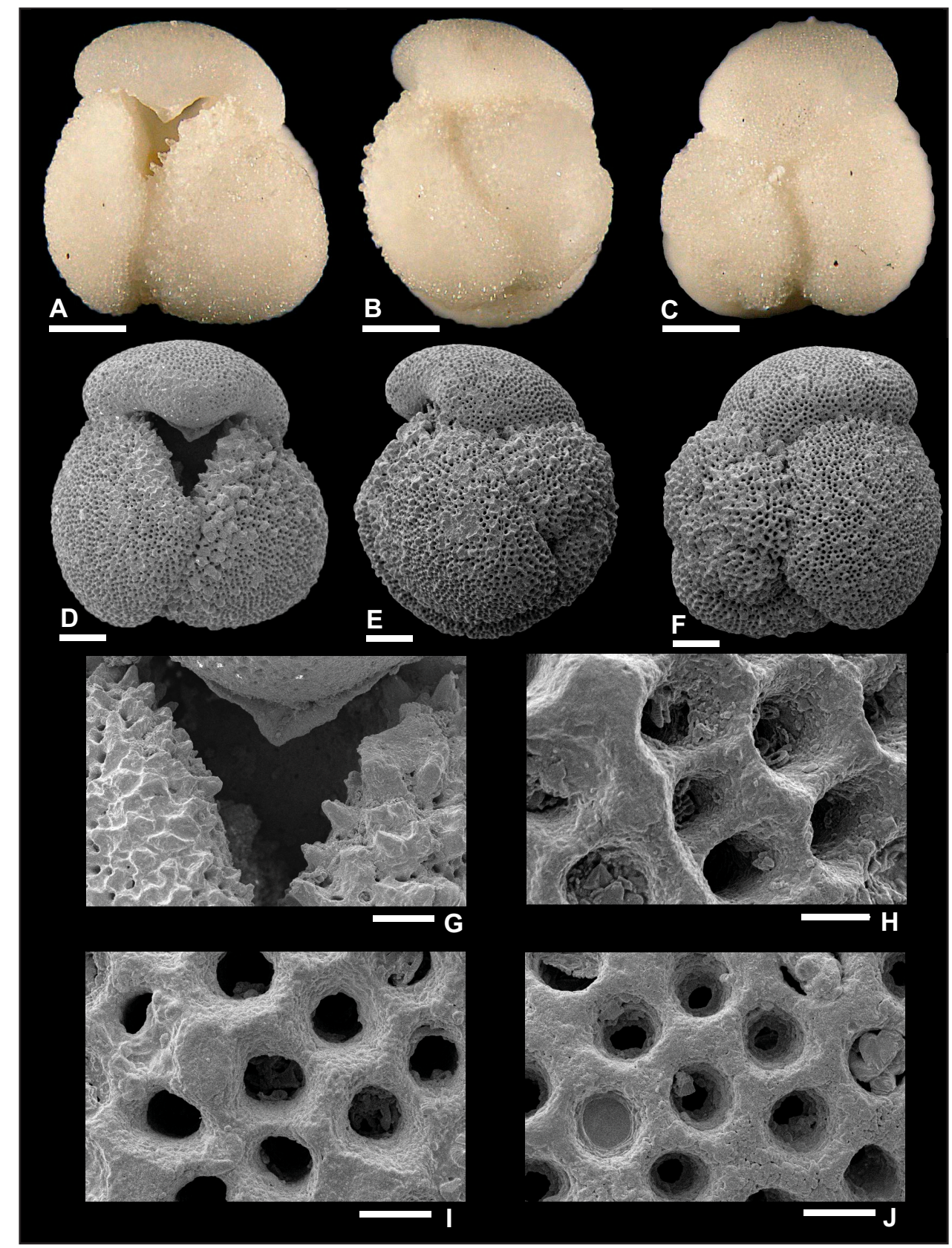


Plate P12. Dentoglobigerina tripartita (S12); Sample 363-U1490A-24H-CC, 11-16 cm; middle Miocene Zone M8. Z-stacker images of (A) umbilical view, (B) edge view, and (C) spiral view. Scanning electron microscope (SEM) images of (D) umbilical view, (E) edge view, and (F) spiral view. Wall texture SEM images of (G) umbilical view and (H) edge view. No evidence of spine holes. Scale bars $=100 \mu \mathrm{m}$ (whole specimens) and $10 \mu \mathrm{m}$ (close-up images).

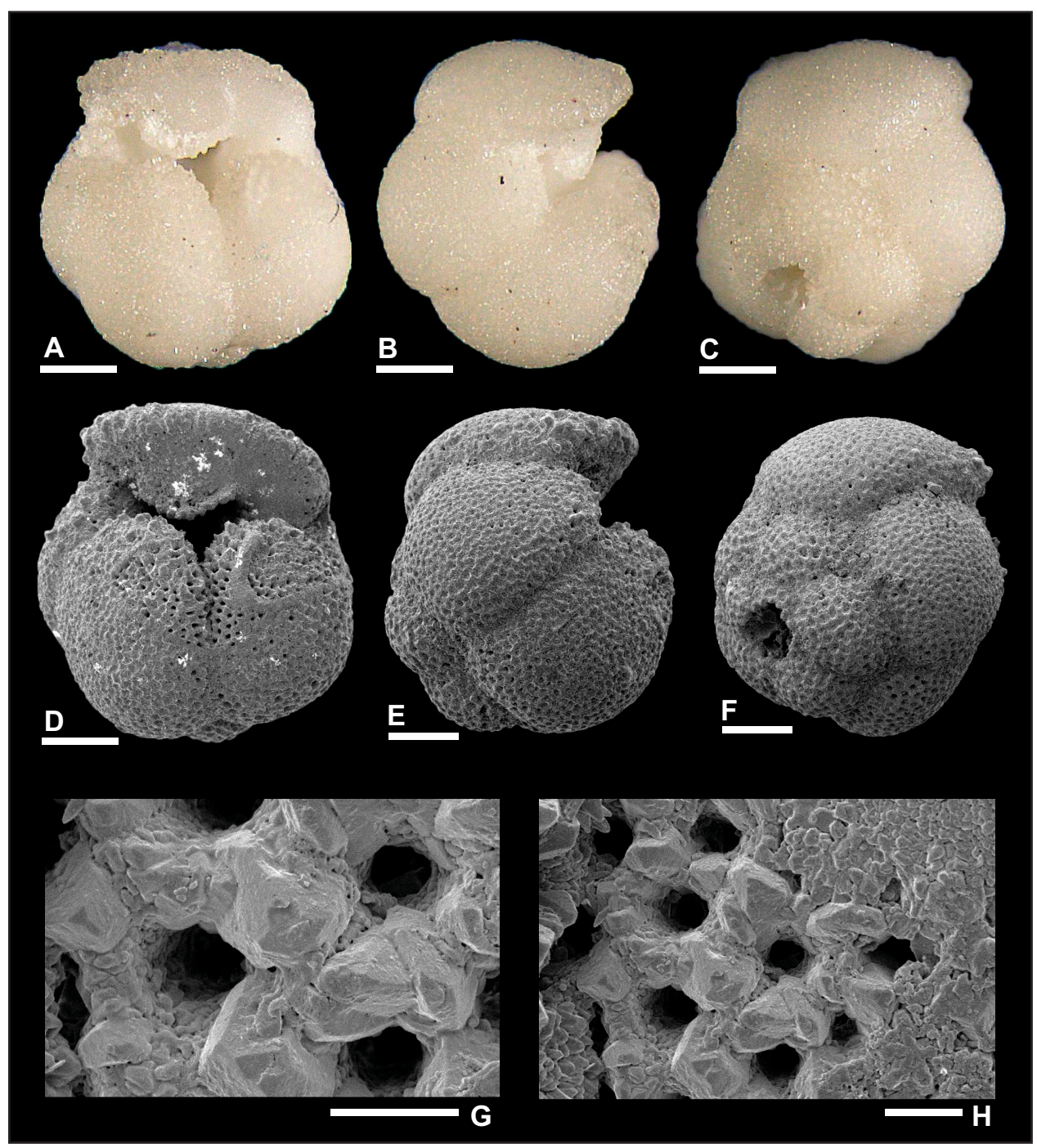


Plate P13. Dentoglobigerina cf. D. tripartita (S13); Sample 363-U1490A-25H-CC, 16-21 cm; lower-middle Miocene Zone M6. Z-stacker images of (A) umbilical view, (B) edge view, and (C) spiral view. Scanning electron microscope (SEM) images of (D) umbilical view, (E) edge view, and (F) spiral view. Wall texture SEM images of $(\mathrm{G})$ umbilical view and $(\mathrm{H})$ edge view. No evidence of spine holes. Scale bars $=100 \mu \mathrm{m}$ (whole specimens) and $10 \mu \mathrm{m}$ (close-up images).

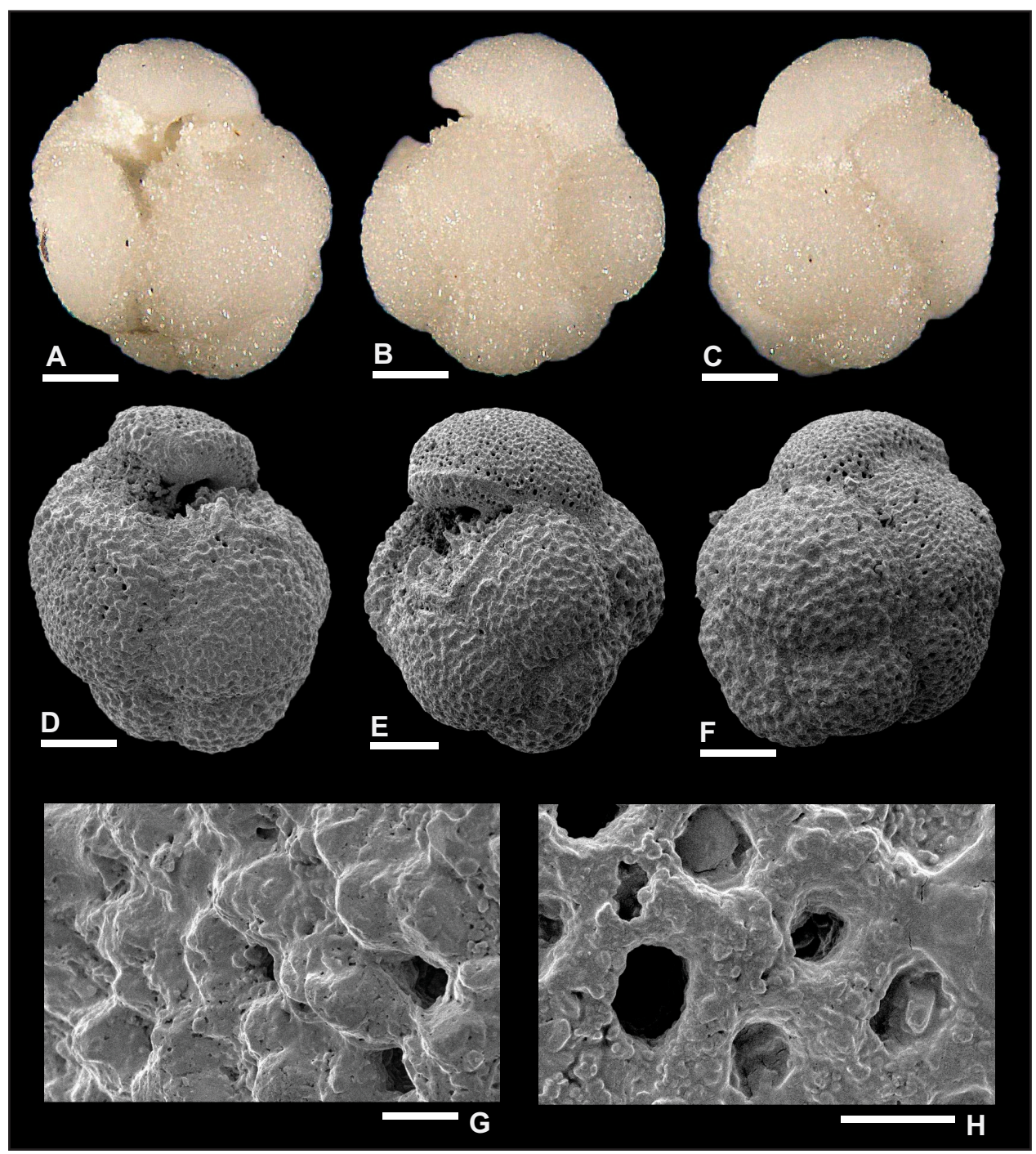


Plate P14. Dentoglobigerina tripartita (S14); Sample 363-U1490A-34X-CC, 32-37 cm; lower Miocene Subzone M1b. Z-stacker images of (A) umbilical view, (B) edge view, and (C) spiral view. Scanning electron microscope (SEM) images of (D) umbilical view, (E) edge view, and (F) spiral view. Wall texture SEM images of (G) umbilical view, (H) edge view, (I) spiral view, and (J) spiral view. No evidence of spine holes. Scale bars $=100 \mu \mathrm{m}$ (whole specimens) and $10 \mu \mathrm{m}$ (close-up images).

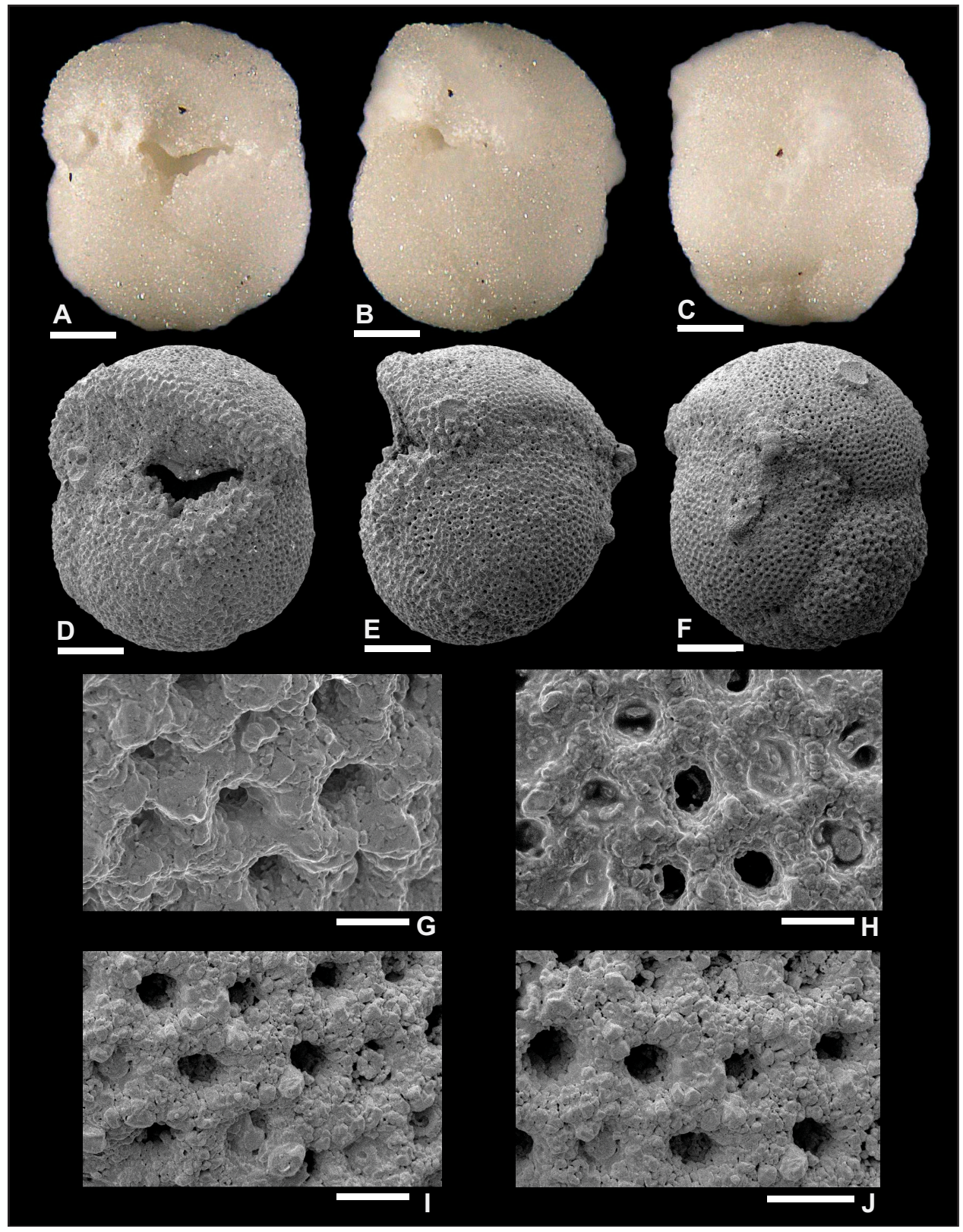


Plate P15. Globoquadrina dehiscens (S15); Sample 363-U1489D-27X-CC, 18-23 cm; lower Miocene Zone M3. Z-stacker images of (A) umbilical view, (B) edge view, and (C) spiral view. Scanning electron microscope (SEM) images of (D) umbilical view, (E) edge view, and (F) spiral view. Wall texture SEM images of (G) umbilical view, (H) edge view, (I) spiral view, and (J) spiral view. No evidence of spine holes. Scale bars $=100 \mu \mathrm{m}$ (whole specimens) and $10 \mu \mathrm{m}$ (close-up images).

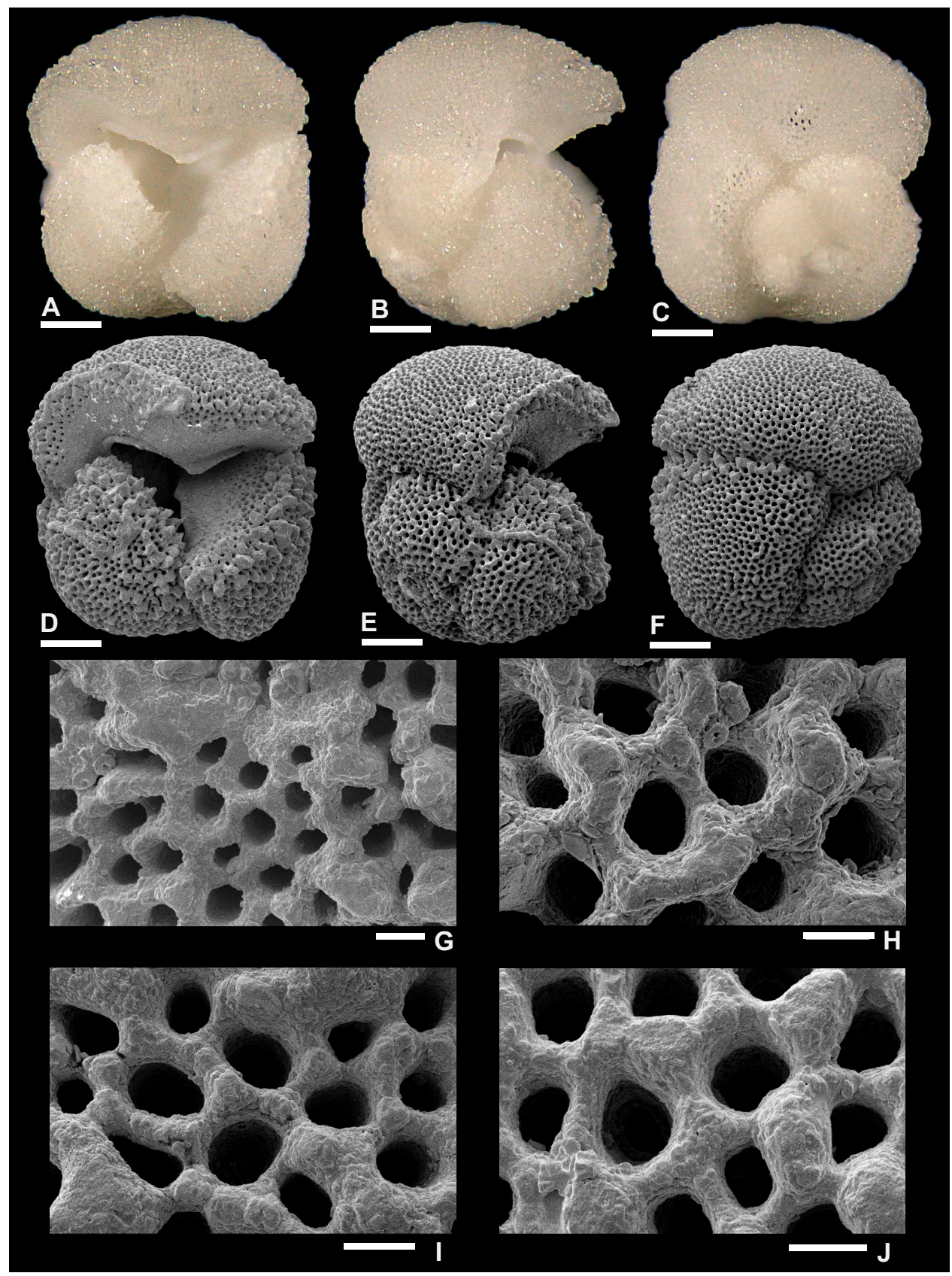

